\title{
GROWTH PERFORMANCE AND PRODUCTION OF OREOCHROMIS NILOTICUS USING POLYCULTURE SYSTEMS AND FERTILIZERS
}

\author{
Mohamed A. Sweilum \\ National Institute of Oceanography and Fisheries, Fish Rearing Lab., \\ El-Kanater El-Khayria Fish Farm, Cairo
}

Key words: Fish farm, growth performance, production, $O$. niloticus, polyculture, fertilizers.

\section{ABSTRACT}

Tile tilapia (Oreochromis niloticus) with an average weight of 40.0 $1 \mathrm{~g}$ were reared with Sarotherodon galilaeus (initial weight of $51.0 \mathrm{~g}$ ) and Clarias gariepinus (initial weight of $73.0 \mathrm{~g}$ ) at three different combinations of monoculture, duoculture and polyculture systems. The fishes were stocked in seven earthen ponds with varied areas at a density of $4 \mathrm{fish} / \mathrm{m}^{2}$ during 210 days and fed on wheat bran. Some rearing ponds were fertilized weekly with a mixture of triple superphosphate and urea.

At the end of the rearing period, the polyculture combination gave better growth rate and production for O.niloticus than in duoculture and monoculture systems. The average monthly increments were $21.1 \mathrm{~g}$ and $29.0 \mathrm{~g}$ in ponds 2,3 (polyculture ponds), while in duoculture and monoculture, $18.7 \mathrm{~g}$ in pond 6 and $16.6 \mathrm{~g}$ in pond 4 were obtained. The specific growth rate and percentage weight gain reached their highest values for O.niloticus $(0.85,4.98$ in pond 3 and $0.73,3.64$ in pond 2) using polyculture combination. On the other hand, O.niloticus showed better growth rate when cultured with Clarias gariepinus than with S.galilaeus. Its average weight was $131.0 \mathrm{~g}$ in pond $6(O$. niloticus with Clarias gariepinus and $128.5 \mathrm{~g}$ in pond 7 (O.niloticus with S.galilaeus).

It was also observed that in the fertilized ponds, maximum growth in weight and production were recorded $(0.379,0.165$ and $0.158 \mathrm{~kg} / \mathrm{m}^{2}$ for the three fish species respectively). In pond 3 (fertilized), the average final weight was $244.0 \mathrm{~g}$ for O.niloticus, $188.5 \mathrm{~g}$ for $S$. galilaeus and $332.0 \mathrm{~g}$ for Clarias gariepinus. The food conversion ratio has also the optimum value (3.14) for O.niloticus reared in polyculture system and fertilized pond. 


\section{INTRODUCTION}

The Nile tilapia (O.niloticus) are considered the most important fish in Egyptian water and are the basis of the fisheries sector, since they represent over 70\% of Egyptian fish landings (Ishak et al., 1985). Attention has been focused on fish farming as having the best potential for achieving new sources of fish production.

The rearing of O.niloticus only (monoculture) or in combination with other fish species as T.zillii or C.carpio (duoculture or polyculture systems) remains one of the most promising methods for increasing of growth rate and marketable size of Tilapia species (Dadzie, 1982). Hogendoorn and Koops (1983) also showed the influence of mixed culture of C.gariepinus and O.niloticus on the growth rate and production in earthen ponds. Furthermore, Macintosh and De Silva (1984) reared O.mossambicus with O.niloticus and O.aureus in a polyculture system and noticed that the growth and survival of cultured fishes varied with different stocking densities and food ration. Similarly, Degani et al. (1985) determined the effects of culturing Anguilla anguilla at various densities with T.aurea on the growth and production.

Other combinatons for O.niloticus with various fish species in polyculture or duoculture systems were used by many authors in different localities with available environmental conditions, types of feeding sources and water quality (El-Serafy et al., 1993; Sweilum, 1995; Abdel-Halim et al., 1997 and Zaghloul, 2000).

On the other hand, the addition of nitrogen and phosphorus as fertilizers to fish ponds stimulates the phytoplankton to increase, which leads to increasing of fish production in ponds (Boyd, 1976). Similarly, Seymour (1980) reported that the carrying capacity and yield of fish ponds can be increased by fertilization which encourages growth of phytoplankton and in turn the amount of food available to the fish. Therefore, most fish ponds are fertilized to increase phytoplanktonic production which increases fish growth and yield (Yusoff \& Mc Nabb, 1997). Moreover, the fertilization also stimulates the growth of the zooplankton organisms in fish ponds which are also considered a main natural food for rearing fish (Jana \& Chakrabarti 1997). Consequently, increasing of phytoplankton and zooplankton organisms in the fish ponds leads to improvement of water quality in ponds (Wahby, 1974; Essa et al., 1988 and Njoku, 1997). The purpose of the present study is to determine the effects of species combination and chemical fertilization on the growth rate 
and total production of Nile tilapia (O.niloticus) in earthen ponds. It deals also with the influence of fertilization on water quality and planktonic production in fish ponds.

\section{MATERIAL AND METHODS}

\section{Site of work:}

The experimental work was conducted in earthen ponds at ElKanater El-Kahyria Fish Farm, National Institute of Oceanography and Fisheries, Cairo, Egypt. The Fish Farm includes seven earthen ponds with different surface areas and stocking density as indicated in Table 1.

The ponds were filled with Nile water and the water depth in ponds ranged from 150 to $155 \mathrm{~cm}$, while water temperature was from 24 to $25^{\circ} \mathrm{C}$ (Table 2).

\section{Fertilization:}

Ponds 1,3 and 5 were fertilized with a mixture of triple superphosphate $\left(6.26 \mathrm{~g} / \mathrm{m}^{2}\right.$ per week) and urea $\left(3.06 \mathrm{~g} / \mathrm{m}^{2}\right.$ per week) according to Wahby (1974) and Green et al. (1989). while the ponds $2,4,6$ and 7 were maintained as control without fertilization.

\section{Feeds and samples:}

Reared fish were fed on wheat bran, five days every week, one time per day at $3 \%$ feeding rate. Water temperature, transparency, and $\mathrm{pH}$ value were measured daily in each pond. Dissolved oxygen, phosphate, ammonia and nitrate were determined biweekly in ponds according to Arnold et al. (1980). The phytoplankton and zooplankton samples were collected monthly from ponds by a plankton net with 20 or 50 micron mesh size, while bottom fauna were collected with a modified Ekman grab (area of $255 \mathrm{~m}^{2}$ ), (Table 3 ). The weight of fish was measured monthly from a random sample in each pond during the period from April, $15^{\text {th }}$ to November, $15^{\text {th }}, 2000$. The specific growth rate (SGR) and percentage weight gain (PWG) were estimated using the equations of Jauncey \& Ross (1982), while the food conversion ratio (FCR) was calculated according to Anderson et al.(1984) formula.

$S G R=[\operatorname{Ln}$ final weight-Ln initial weight $/$ Rearing period (day) $] \times 100$. $\mathrm{PWG}=[$ Final weight- Initial weight / lnitial weight $] \times 100$.

$\mathrm{FCR}=[$ Food given $/$ Gain in weight $] \times 100$. 
Statistical analysis:

The means of the experimental results were statistically analysed using students $T$ Test and $F$ test of significance as described by Berlly \& Lindgren (1990) applying the following:

$T$ calculated value $=x_{1}^{-}-x_{2}^{-} / \frac{S_{1}}{\sqrt{n_{1}}}+\frac{S D_{2}}{\sqrt{n_{2}}}$.

$\mathrm{F}$ calculated value $=$ Mean square to treatment $/$ Mean square to error.

\section{RESULTS AND DISCUSSION}

The results indicate that the weight of $O$. niloticus reared in pond 2 (polyculture system) increased from an average of $40.5 \mathrm{~g}$ to $188.0 \mathrm{~g}$ (Table 4) at the end of rearing period (210 days), while in pond 6 (duoculture) and 4 (monoculture) the initial weight (40.0 and $41.0 \mathrm{~g}$ ) increased to 171.0 and $157.5 \mathrm{~g}$. It was also noticed that the mean increment of fish reached its highest value $(21.1 \pm 3.5 \mathrm{~g}$ monthly) in pond 2 and the lowest value (16.6 $\pm 7.8 \mathrm{~g}$ monthly) in pond 4. F- test of significance shows that the differences between the average increment of Oniloticus (Table 5) reared in three combinations (poly,duo and monoculture) were insignificant( $p>$ $0.05)$.

The present results suggested that the growth rate of Nile tilapia was higher in polyculture system than in duo or monoculture and the duoculture was better than monoculture system. Consequently, the specific growth rate and percentage weight gain reached their maximum values ( 0.73 and 3.64) for O.niloticus reared in polyculture system, while the minimum values $(0.64$ and 2.84$)$ were observed in monoculture. The total production of $O$. niloticus was $243.38 \mathrm{~kg} /$ pond corresponding to $\mathrm{kg} /$ feddan in polyculture system (pond 2) and 110.68 $\mathrm{kg} /$ pond corresponding to $\mathrm{kg} / \mathrm{feddan}$ in monoculture system (pond 4), (Table 6). This may be attributed to the variety of feeding behaviour and metabolic activity of the reared fish species. In turn, there is no competition for supplementary or natural food between the reared fishes. Thus the increase of stocking density of one species in the rearing ponds may lead to a decrease of growth rate.

Thus the present findings agree with those of previous investigators, among them, Dadzie (1982) who reared O.niloticus in different cultured systems with $T$.zillii and C.carpio and noticed that 
$O$. niloticus had the fastest growth when raised in polyculture with T.zillii and $C$. carpio, while in case of duoculture $(O$. niloticus with $T$. zillii) and monoculture ( $O$. niloticus only) the poorest growth rate was recorded. Similarly, Hogendoorn \& Koops (1983) mentioned that the growth of neither Nile tilapia (O.niloticus) nor Nile catfish ( $C$.gariepinus) was found to be affected by the presence of the alternate species, indicating the absence of interspecies competition.

The same trend was also postulated by Macintosh \& De Silva (1984) when stocked $O$. niloticus with $O$. mossambicus and $O$. aureus in a polyculture system at different stocking densities and observed that the increasing of stocking density leads to elevation of the mortality, consequently decreasing of weight gain and production. Degani et al. (1985) stocked A.angilla at different densities in monoculture and polyculture systems with $O$. aureus and noticed that the growth of $A$.anguilla was more rapid in a polyculture system with low density than those of monoculture with high density.

On the contrary, Jobling et al. (1998) reared the baltic salmon (Salmo salar) with brown trout (Salmo trutta) in monoculture and duoculture systems for three months and observed that salmon cultured in duoculture ponds $(223 \pm 9.0 \mathrm{~g})$ tended to have lower body weights than those reared in monoculture (242 $\pm 10.0 \mathrm{~g}$ ). Such discrepancy between the result of Jobling ef al. (1998) and the present study may be due to the variety of experimental conditions (water temperature was $2.7-3^{\circ} \mathrm{C}$ and the fish reared in tanks, $0.35 \mathrm{~m}^{3}$ ) and the salmon fed on a commercial diet containing $46 \%$ protein level with twice feeding frequency per day.

On the other hand, the final weight $(171.0 \mathrm{~g})$ and monthly average increment $(18.7 \pm 4.9 \mathrm{~g})$ of O.niloticus reared in pond 6 (O. niloticus with $C$. gariepinus ) were more than in pond 7 (O. niloticus with $S$. galilaeus). Statistical analysis with $\mathrm{T}$ test showed that, the difference between the average increment in ponds 6 and 7 was not significant $(p>0.05)$. This may be mainly because C. gariepinus is a carnivorous fish, preying on fry produced from the experimental fish during the rearing period. Thus the supplementary food was eaten by reared fish and not by producing fry. The same observations were also mentioned by Hassanen (1987) and El-Agamy et al. (1992) in their studies on culture of C. gariepinus.

Table (2) shows the effect of chemical fertilizers (triple super phosphate and urea) on water quality of rearing ponds. It was noticed that, the transparency of pond water reached its highest values (71.2, 
60.6 and $65.7 \mathrm{~cm})$ in non fertilized ponds $(2,4$ and 6$)$ while the lowest values $(32.3,30.5$ and $35.0 \mathrm{~cm})$ in fertilized ponds $(1,3$ and 5$)$. This is due to the high fertility of ponds water with increasing of phytoplankton and zooplankton organisms. Consequently, the dissolved oxygen, phosphate and nitrate reached their maximum values $(8.8,1.8$ and $4.7 \mathrm{mg} / 1)$ in the fertilized pond 3 at which the concentration of ammonia had the lowest limit $(1.1 \mathrm{mg} / \mathrm{l})$ and $\mathrm{pH}$ value has a suitable value (7.4). This may be attributed to increase of photosynthesis with increasing Chlorophyta in the ponds which leads to elevation of oxygen level and lowering of carbon dioxide $\left(\mathrm{CO}_{2}\right)$ which in turn influences the $\mathrm{pH}$ value and other chemical characteristics of ponds water. These observations are in accordance with the fendings of Wahby (1974), Tuburan et al. (1989) and Njoku (1997).

Examination of pond water showed that the maximum number of phytoplankton organisms $(17700,23700$ and 20800 cell/l) were observed in fertilized ponds (1,3 and 5) and Chlorophyta (green algae) was the most abundant group (44.3\%), (Table 2). while the lowest numbers $(1200,7200$ and 8000 cell $/ 1)$ were recorded in non fertilized ponds (2,4 and 6). Seymour (1980) reported that the production of fish ponds can be increased by fertilization which encourages growth of phytoplankton and in turn the amount of food available to the rearing fish. Spataru et al.(1983) studied the natural food of carp and tilapia species reared in fertilized ponds and noticed that there was a high dominance for plankton organisms in water and in gut of fishes after fertilization of the ponds.

Similarly, Green et al.(1989) observed that the addition of nitrogen and phosphorus fertilizers to fish ponds (triple superphosphate and urea) stimulates the productivity of phytoplankton organisms, thus increasing tilapia production in the ponds. The same observations were also recorded by Knud-Hansen \& Batterson (1994) who mentioned that most of fish culture ponds were fertilized to increase phytoplanktonic production which would increase fish yield. Furthermore, Yusoff \& Mc Nabb (1997) found that addition of combined triple superphosphate and urea to fish ponds not only significantly increased $(p>0.05)$ total phytoplankton densities, but also caused a shift from Cyanophyta (blue -green algae) dominance to Chlorophyta (green algae).

On the other hand, addition of fertilizers to fish ponds stimulates the increase of zooplankton and benthos in ponds. Table (3) shows that the highest number of zooplankton organisms $(620,740$ 
and 690 cell / 1 ) was observed in fertilized ponds (1,3 and 5) with the dominance of cladoceran spp. (31.16\%). The bottom fauna (benthos) which was represented by chironomid larvae and tubifex worms also increased in fertilized ponds $\left(82,117\right.$ and 100 organism $\left(\mathrm{m}^{2}\right)$ than that in non fertilized ones. Rappaport et al.(1977) mentioned that the number of zooplankton and chironomid larvae which are the most important source of natural food for freshwater fishes (carp and tilapia) were highly increased by addition of organic and inorganic fertilizers to the fish ponds.

Furthermore, Groeneweg \& Schlüter (1981) made a mass culture of rotifers (Brachionus sp.) by fertilization of fish sponds with organic fertilizers. Similarly, Geiger (1983) reported that zooplankton production and manipulation in striped bass rearing ponds were carried out by using a combination of organic and inorganic fertilizers. Essa et al. (1988) noticed that, the zooplankton production increased significantly $(p<0.05)$ in fish ponds by addition of fertilizer compounds which provides a continuous supply of organic matter containing elements (carbon, nitrogen and phosphorus) required for increasing the natural food for fishes, while Jana \& Chakrabarti (1997) used different rates and frequencies of organic fertilizers for the culture of cladoceran zooplankton (Daphnia sp.).

Generally, the present results indicated that the growth rate and production of the cultured fish were higher in fertilized ponds which had a high water fertility and suitable water quality. The final weight and average increment of $O$. niloticus in pond 3 (244.0 and $29.0 \mathrm{gm})$ were more than in pond $2(188.0$ and $21.1 \mathrm{~g}$ ) (Table 4). The difference between the average increment in the two ponds was significant at $5 \%$ $(p<0.05)$ and insignificant at $1 \%(p>0.01)$. Table (6) shows that the total fish production of O.niloticus was $455.17 \mathrm{~kg}$ in pond 3 (fertilized) and $243.38 \mathrm{~kg}$ in pond 2 (non fertilized). On the other hand, the specific growth rate and percentage weight gain of the cultured fishes were higher in pond 3 (fertilized) than in pond 2 (non fertilized). The same observations were also recorded by Green et al.(1989), El- Serafy et al.(1993) and Nojku (1997).

\section{REFERENCES}

Abdel-Halim, A.M.; Al-Zahaby, A.S. and Soliman, A.M. (1997). Food and feeding habits of black carp. II -Feeding efficiency and biological control of snails in fish ponds. Bull. Sci., Zagazig Univ., 19: 120- 231. 
Al-Zahaby, A.S.; El-Agamy, A.E.; El-Serafy, S.S. and Badawy, E.A. (1987). Preliminary observations on the relative growth and production of Tilapia species cultured in cages at three stocking densitjes. Qatar Univ. Sci. Bull., 7 : 343-361.

Anderson, J.; Jackson, A.J.; Matty, A.J. and Copper, B.S. (1984).Effects of dietary carbohydrate and fiber on tilapia (Oreochromis niloticus). Aquacult., 37: 303-314.

Arnold, E.G.; Joseph, J.C. and David, J. (1980). Standard Methods for the Examination of Water and Waste Water. $15^{\text {th }}$ ed. American Public Health Association. Washington, DC, 20005.

Berly, D.A. and Lindgren, B.W. (1990). Statistics, Theory and Method. Brooks / Cole Publishing Company Pacific Grove, California, PP. 93-121, 186-242, 364-397.

Boyd, C.E. (1976). Nitrogen fertilizer effects on production of tilapia in ponds fertilized with phosphorus and potassium. Aquacult., 7: $385-390$.

Dadzie, S. (1982). Species combination in tilapia culture. Aquacult., 27: $295-299$.

Degani, G.; Levanon, D. and Dosoretz, C. (1985). Growth of Anguilla anguilla in different densities in outdoor containers with Tilapia aurea. Prog. Fish Cult.,47: 114-117.

El-Agamy, A.E.; Labib, W.; El-Serafy, S.S. and El-Kashif, M.A. (1992). Observations on the growth of Clarias lazera reared in cages at three stocking rates. J. Appl. Sci., 7: 484-491.

El-Serafy, S.S.; El-Gamal, A.A.; AI-Zahaby, A.S. and Abdel -Nasser, G. (1993). Polyculture of six fish species under different management systems in Egypt. Bull. Nat. Inst. Oceanogr. \& Fish., $19: 363-377$.

Essa, M.A.; Salama, M.E. and Soliman, A.K. (1988). A comparative study on production and economic of integrated duck-fish and inorganic fertilizer supplementary feed fish culture systems. Bull. Nat. Inst. Oceanogr. \& Fish., 14: 31 -38. 
Geiger, J.G. (1993). Zooplankton production and manipulation in striped bass rearing ponds. Aquacult., $35: 331-351$.

Green, B.W.; Phelps, R.P. and Alvarenga, H.R. (1989). The effect of manures and chemical fertilization on the production of Oreochromis niloticus. Aquacult. 76: 37-42.

Groeneweg, J. and Schluter, M. (1981). Mass production of freshwater rotifers on liquid wastes. II. Mass production of Brachionus rubens in the effluent of high-rate algal ponds used for the treatment of piggery waste. Aquacult., 25:25-33.

Hassanen, G.D. (1987). Feeding experiments on the Nile catfish (Clarias lazera) reared in cages. Proc. Zool. Soc., Egypt, 14: $155-168$.

Hogendoorn,H. and Koops, W.J. (1983). Growth and production of the African catfish (C.lazera).I. Effects of stocking density, pond size and mixed culture with tilapia (Sarotherodon niloticus) under extensive field conditions. Aquacult., 34: 253-263.

Ishak, M.M.; Sayes, A. and Tallaat, K. (1985). Tilapia fisheries in Lake Borollus (Egypt). Kuwait. Bull. Mar. Sci.,6:225 - 242.

Jana, B.B. and Chakrabarti, L. (1997). Effect of manuring rate on in situ production of zooplankton (Daphnia carinata). Aquacult., 156: $85-99$.

Jauncey, K. and Ross, B. (1982). "A Guide to Tilapia Feeds and Feeding". Published at the University of Stirling, Scotland, U.K. $9: 4$ pp.

Jobling, M.; Koskela, J. and Pirhonen, J.(1998). Feeding time, feed intake and growth of baltic salmon (Salmo salar) and brown trout (Salmo trutta) reared in monoculture and duoculture at constant low temperatures. Aquacult., 163:73 84.

Knud-Hansen, C.F. and Batterson, T.R. (1994). Effect of fertilization on the production of Nile tilapia (Oreochromis niloticus). Aquacult., $123: 271-280$. 
Macintosh, D.J. and De Silva, S.S. (1984). The influence of stocking density and food ration on fry survival and growth in Oreochromis mossambicus and $O$. niloticus female $\mathrm{x}$ $O$.aureus male hybrids reared in a closed circulated system. Aquacult., $41: 345-358$.

Njoku, D.C. (1997). Effect of different manure levels on fish growth, mortality and yield in a horizontally integrated fish -cum. poultry farming system in Nigeria. Aquacult.Res., 28:65I660.

Rappaport, U.; Sarig, S. and Bejerano, Y. (1977). Observations on the use of organic fertilizers in intensive fish farming at the ginosar station. Bamidgeh, $29: 57-70$.

Seymour, E.A. (1980). The effects and control of algal blooms in fish ponds. Aquacult., $19: 55-74$.

Spataru, P. Wohlfarth; G.W. and Hulata, G. (1983): Studies on the natural food of different fish species in intensively manured polyculture ponds. Aquacult., $35: 383-298$.

Sweilum, M.A. (1995). Studies on rearing of some available species of carp and tilapia in ponds. Ph. D. Thesis. Fc. of Sci. Zagazig Univ. (Benha Branch), 288 pp.

Tuburan, B.I.; Agbayani, R.F. and Subosa, P.F. (1989). Evaluation of organic and inorganic fertilizers in brackishwater milkfish ponds. Aquacult., $76: 227-235$.

Wahby, S.D. (1974): Fertilizing fish ponds. I-Chemistry of the waters. Aquacult., $3: 245-259$.

Yusoff, F.M. and Mc Nabb, C.D. (1997). The effects of phosphorus and nitrogen on phytoplankton dominance in tropical fish ponds. Aquacult. Res., $28: 591-597$.

Zaghloul, K.H. (2000). Effect of different water sources on some biological and biochemical aspects of the Nile tilapia (Oreochromis niloticus) and the Nile catfish (Clarias gariepinus). Egypt. J. Zool., 34: $353-377$. 
Table 1. Fish ponds and stocking densities

\begin{tabular}{|c|c|c|c|c|c|}
\hline \multirow[t]{2}{*}{ Pond No } & \multirow{2}{*}{$\begin{array}{l}\text { Pond area } \\
\left(\mathrm{m}^{2}\right)\end{array}$} & \multicolumn{4}{|c|}{ Fish species and stocking density ( $4 \mathrm{fish} / \mathrm{m}^{2}$ ) } \\
\hline & & O.niloticus & S.galilaeus & C.gariepimus & $\begin{array}{l}\text { Stocking } \\
\text { rates }\end{array}$ \\
\hline 1 & 450 & 900 & 900 & - & $1: 1$ \\
\hline 2 & 900 & 1800 & 1200 & 600 & $3: 2: 1$ \\
\hline 3 & 1200 & 2400 & 1600 & 800 & $3: 2: 1$ \\
\hline 4 & 300 & 1200 & - & - & - \\
\hline 5 & 750 & 2250 & - & 750 & $3: 1$ \\
\hline 6 & 800 & 2400 & - & 800 & $3: 1$ \\
\hline 7 & 525 & 1050 & 1050 & - & $1: 1$ \\
\hline
\end{tabular}








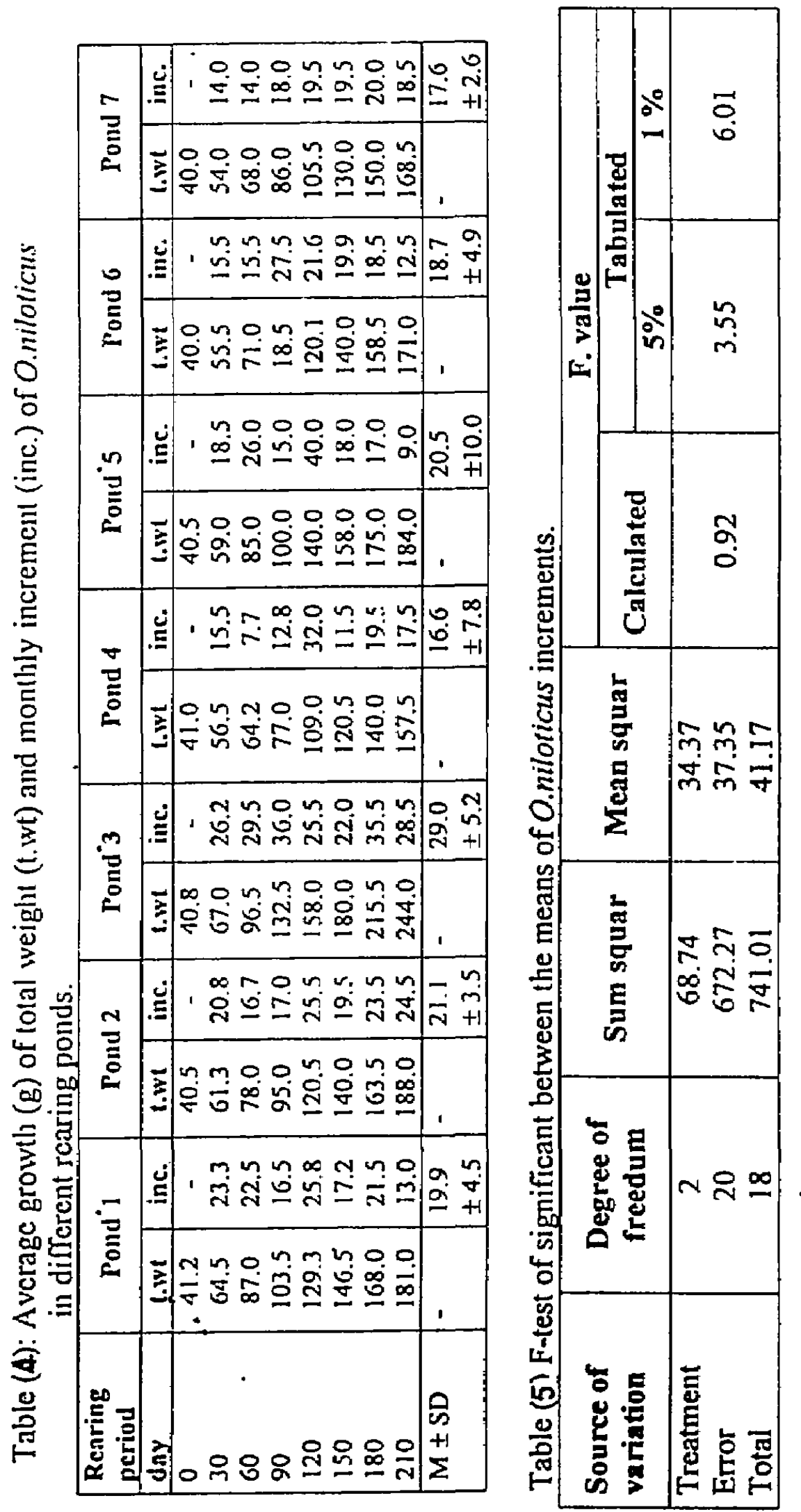


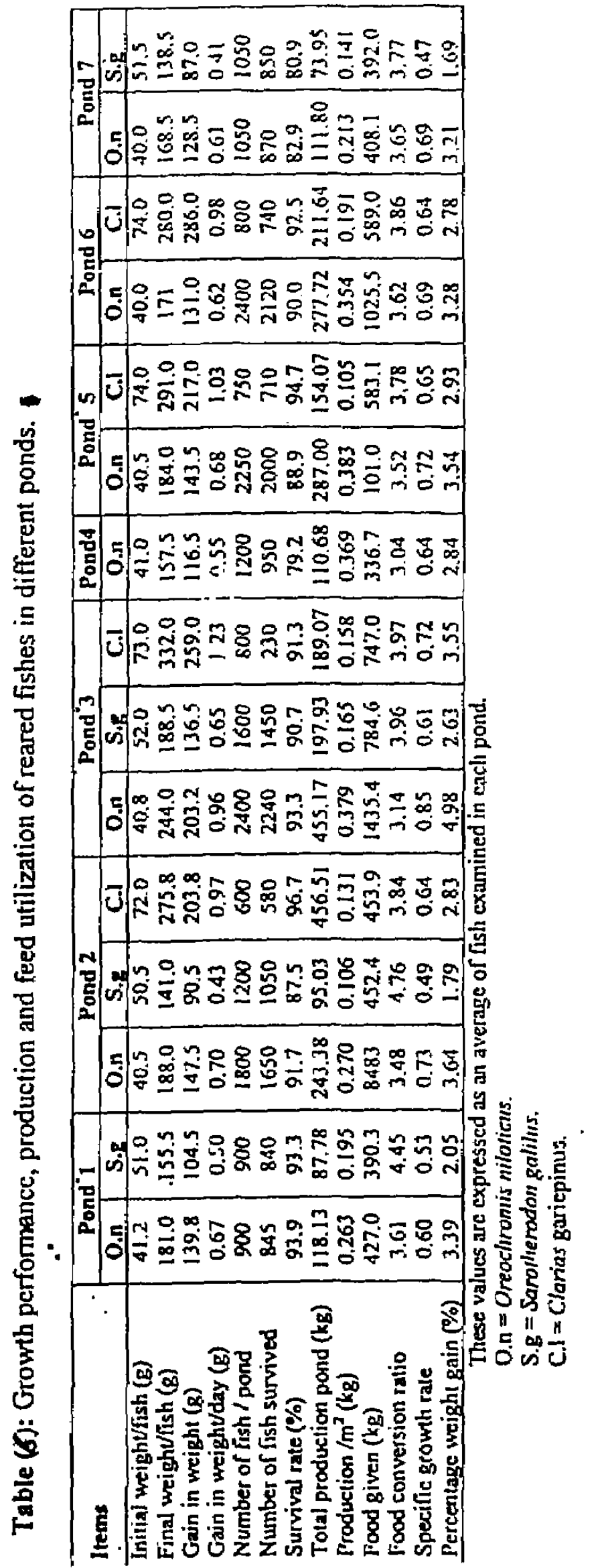

